\title{
Tackling Air Pollution in Krakow
}

\author{
Artur Jachimowski ${ }^{1, *}$, Marcin Paprocki ${ }^{1}$, Magdalena Wojnarowska ${ }^{1}$ \\ ${ }^{1}$ Chair of Product Technology and Ecology, Faculty of Commodity Science and Product \\ Management, Krakow University of Economics, Rakowicka 27, 31-510 Kraków, Poland
}

\begin{abstract}
Data used in order to determine the level of pollutants present in the air in Krakow came from three air quality monitoring stations located in Bulwarowa street, Bujaka street and Krasińskiego avenue. Based on these data, an analysis was performed concerning air quality in Krakow in 2010-2016. Also, a correlation analysis was performed to investigate the relation between air quality parameters and meteorological parameters, such as: wind, precipitation, temperature. An analysis of the results obtained showed that two factors are critical for the variability of air pollution in Krakow. The first of them is low-stack emissions from coal stoves and boilers. The other factor is the type of atmospheric circulation. It has been determined that the worst air quality occurs in the heating season as the prevailing circulation is anticyclonic (high-pressure) characterised by low temperature, lack or small amount of precipitation, weak wind and thermal inversion. The paper presents preventive measures aimed at reducing the amount of pollutants in Krakow. It has been found that in order to reduce the level of air pollution in Krakow, especially in the heating season, it is necessary to intensify operations aimed at eliminating coal and wood stoves and boilers.
\end{abstract}

\section{Introduction}

Air pollution is considered to be one of the main reasons causing deterioration of the state of environment [1]. This includes solid, liquid and gaseous substances or wave energy introduced into the atmosphere in amounts or intensity harmful to the environment. Both the substances mentioned above and the energy introduced have the ability to persist in the atmosphere for a certain time. Therefore, they have an adverse effect on the biosphere as well as other elements of the environment [2]. World Health Organisation defines air pollutants as any air contamination or substance that has a harmful effect on the health or is dangerous for other reasons regardless of its physical form. Air pollutants are the most harmful and dangerous of all pollutants because they are mobile and can contaminate virtually all environmental components over large areas [3].

Excessive air pollutions affect over $20 \%$ of the area of Poland, and the factors that cause this state are considered to be, inter alia, commercial and industrial power generation, industrial technologies, other stationary sources (which include local heat-only boiler

\footnotetext{
*Corresponding author: artur.jachimowski@uek.krakow.pl
} 
stations, domestic furnaces, workshops, agriculture and others) as well as mobile sources [4].

The paper presents results of investigations into selected air pollutants in Krakow in 2010-2016. Based on the analysis performed, the factors impacting the air quality were identified and solutions reducing their adverse effects were proposed.

\section{The causes of air pollution}

The main sources of primary energy supply in Poland are hard coal, lignite, oil and natural gas, where solid fuels prevail in the national fuel consumption pattern [5]. The fundamental source of air pollutants is indicated to be anthropogenic emission related to industrial activity as well as traffic emission. The energy and metallurgical industries are the greatest sources of dust pollution. The state of air quality is affected by emissions of pollutants into the air from the territory of Poland and cross-border transportation, but also meteorological conditions [6].

An essential factor that determines the impact of pollutants emitted into the atmospheric air is the height of the source of emission. With high sources of emissions, pollutants emitted at high altitudes are transported over great distances. This means that their influence on local air pollution is small. On the other hand, with low sources of emissions transport of pollutants is hampered (due to blending in the air). This results in the occurrence of high concentrations of pollutants in the ground layer close to the source of emission. This implies that emissions at low altitudes have a particularly adverse effect on the local state of pollution [7].

In Poland $90 \%$ of dust pollution breaches are accounted for by domestic heating installations. Traffic, in turn, mainly cars with diesel engines, accounts for approx. 5-10\% of exceedances of the limit values [8]. According to the State Environment Monitoring, in 2013 the proportion of individual heating of buildings in the sources accountable for exceeding the permissible PM10 level was over $88 \%$ on a nationwide scale [9].

A similar situation prevails in Krakow where the essential factors having an impact on the degree of air pollution are emissions from industrial plants and low-stack emissions from coal furnaces and boilers. As shown in Figure 1a, dust pollution emissions from particularly noxious plants in Krakow was steadily decreasing in 2010-2016. In turn, Figure $1 \mathrm{~b}$ shows the increasing dynamics of the process of eliminating coal furnaces and boilers in 2012-2016. In 2012, 375 coal furnaces and 16 boilers were eliminated, and in 2016, 2002 coal furnaces and 2240 boilers. 
a)

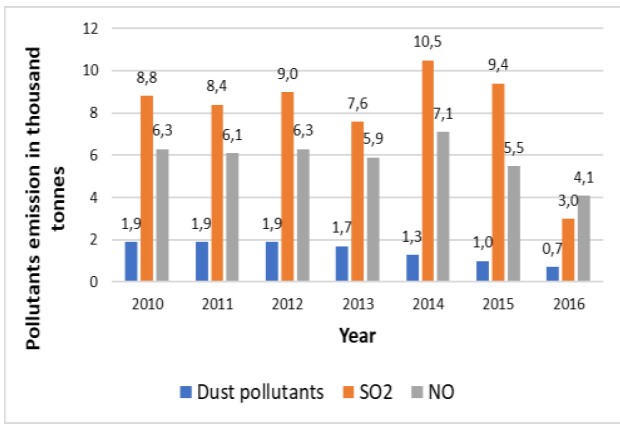

b)

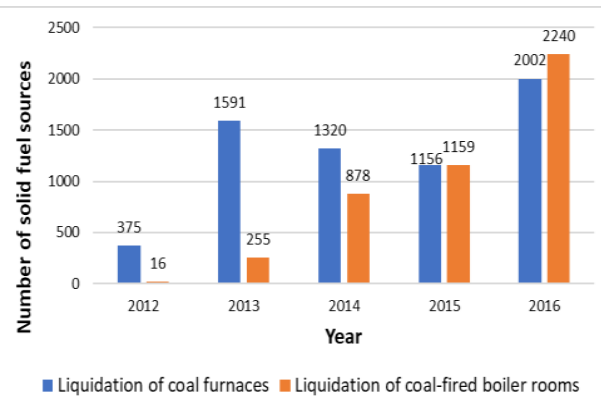

Fig. 1. a) Pollutant emissions from particularly noxious plants in Krakow, b) Reduction of low-stack emissions in Krakow in 2012-2016.

Source: own work based on data [10], [11]

\section{Methodology}

Data from an air quality monitoring system were used in order to determine the level of pollutants emitted into the atmosphere in Krakow. Automated monitoring was carried out for three stations located at Bulwarowa street (the district of Nowa Huta), Bujaka street (the district of Kurdwanów) and Krasińskiego avenue in 2010-2016. A number of gas analysers, selectively sensitive to a particular pollutant type were used. Measurements of samples were taken on a continuous basis, and due to direct marking it was possible to obtain measurement results on an ongoing basis. Results of the analyses provided by the Regional Inspectorate for Environmental Protection in Krakow [12].

For selected air quality indicators the basic statistical parameters were calculated: the average, minimum and maximum values, standard deviation (SD), coefficient of variation (CV) as well as the number of months in which the threshold values were exceeded for the individual pollutants. Furthermore, the Pearson's linear correlation coefficient was determined in order to assess the strength of correlation between the monthly average air quality parameters in the study period. The meteorological indicators taken into account here included the average monthly temperature, the average monthly total precipitation [10] and the average monthly wind velocity [13].

\section{Analysis and discussion of results}

This chapter presents the detailed statistical analyses that were performed for selected substances polluting the air in Krakow. The data that have been accumulated over the seven-year-long study period included air quality parameters analysed in the period between 1st January 2010 and 31st December 2016. The study took into account measurement stations located in different areas of Krakow.

\subsection{Air quality analysis}

In the assessment of the state of air selected quality indicators were used: sulphur dioxide $\left(\mathrm{SO}_{2}\right)$, carbon monoxide $(\mathrm{CO})$, nitric oxide $(\mathrm{NO})$, nitrogen dioxide $\left(\mathrm{NO}_{2}\right)$, nitrogen oxides $\left(\mathrm{NO}_{\mathrm{x}}\right)$, suspended particulate matter PM10 and PM2.5. The parameters selected were characterised by the greatest representativeness over the study period. At the same time, 
these parameters determine to the greatest extent the quality of air in Krakow. Table 1 presents statistical analyses of the results over a period of 84 months (2010-2016).

Table 1. Content of pollutants in the air in Krakow in 2010-2016.

\begin{tabular}{|c|c|c|c|c|c|c|c|}
\hline \multirow{2}{*}{ Location } & \multirow{2}{*}{ Indicator } & Average & Min. & Max. & SD & Limit $^{1)}$ & \multirow{2}{*}{$\begin{array}{c}\text { CV } \\
\% \\
\end{array}$} \\
\hline & & \multicolumn{5}{|c|}{$\left[\mu \mathrm{g} / \mathrm{m}^{3}\right]$} & \\
\hline \multirow{4}{*}{ Krasińskiego } & $\mathrm{CO}$ & 1054.54 & 557.00 & 2061.00 & 365.27 & - & 34.64 \\
\hline & $\mathrm{NO}_{\mathrm{x}}$ & 230.04 & 145.00 & 341.00 & 46.37 & 30 & 20.16 \\
\hline & PM10 & 67.17 & 27.00 & 147.00 & 31.38 & 40 & 46.71 \\
\hline & PM2.5 & 47.51 & 18.00 & 122.00 & 26.35 & 25 & 55.47 \\
\hline \multirow{4}{*}{ Kurdwanów } & $\mathrm{SO}_{2}$ & 7.83 & 1.90 & 39.00 & 6.46 & 20 & 82.43 \\
\hline & $\mathrm{NO}_{\mathrm{x}}$ & 82.03 & 38.00 & 168.00 & 34.94 & 30 & 42.60 \\
\hline & PM10 & 47.93 & 20.00 & 137.00 & 25.44 & 40 & 53.08 \\
\hline & PM2.5 & 33.28 & 11.00 & 109.00 & 21.08 & 25 & 63.35 \\
\hline \multirow{5}{*}{ Nowa Huta } & $\mathrm{SO}_{2}$ & 8.37 & 3.00 & 27.00 & 5.24 & 20 & 62.68 \\
\hline & $\mathrm{CO}$ & 625.18 & 298.00 & 1350.00 & 235.32 & - & 37.64 \\
\hline & $\mathrm{NO}_{\mathrm{x}}$ & 60.94 & 32.00 & 120.00 & 24.45 & 30 & 40.13 \\
\hline & PM10 & 52.34 & 20.00 & 113.00 & 25.46 & 40 & 48.64 \\
\hline & PM2.5 & 35.49 & 12.00 & 95.00 & 20.65 & 25 & 58.18 \\
\hline
\end{tabular}

1) Regulation of the Minister of Environment of 24th August 2012 on Air Levels of Certain Substances (Journal of Laws of 2012, item 1031) [14]

Source: own work based on [12]

Changes in air pollution in Krakow over the study period have been presented in Figures 2-4. The air pollution indicators have been broken down into two groups, gaseous and particulate.

a)

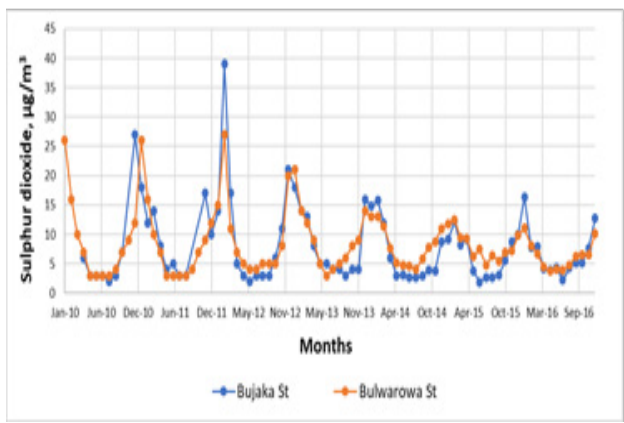

b)

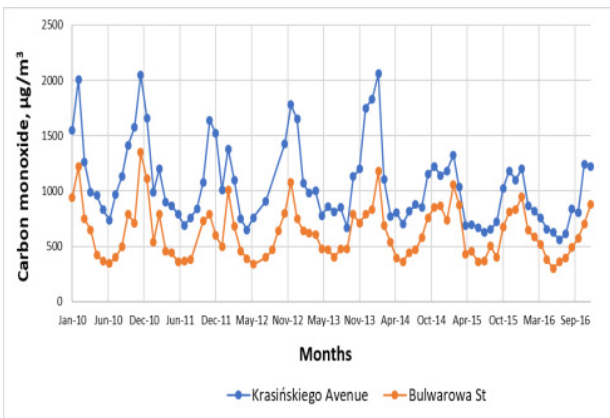

Fig. 2. a) $\mathrm{SO}_{2}$ content in the air in Krakow in $2010-2016$, b) $\mathrm{CO}$ content in the air in Krakow in 2010-2016.

Source: own work based on [12] 


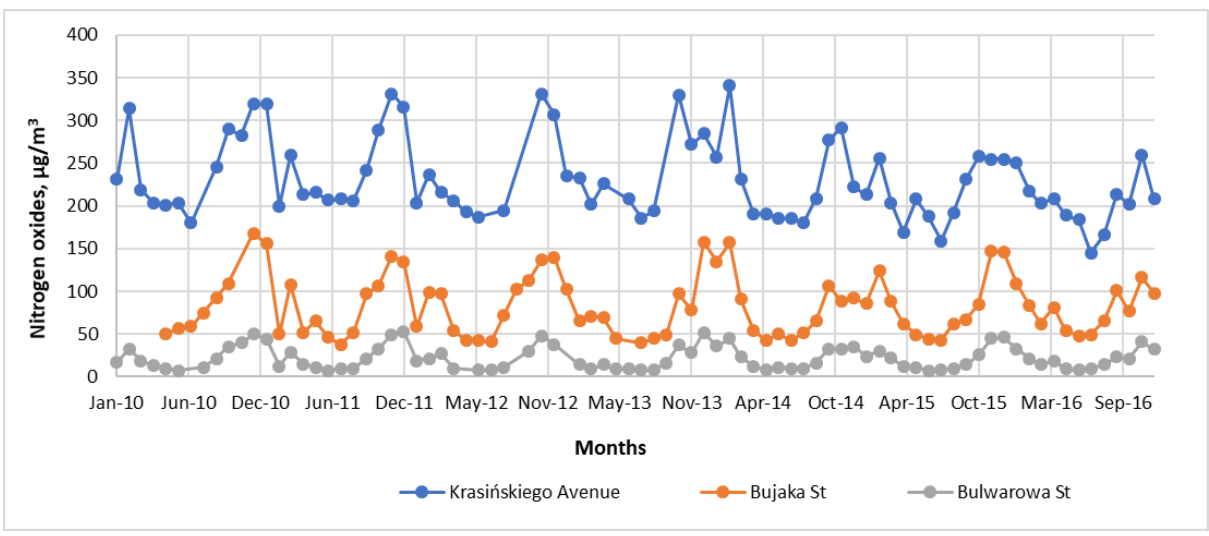

Fig. 3. $\mathrm{NO}_{\mathrm{x}}$ content in the air in Krakow in 2010-2016.

Source: own work based on [12]

a)

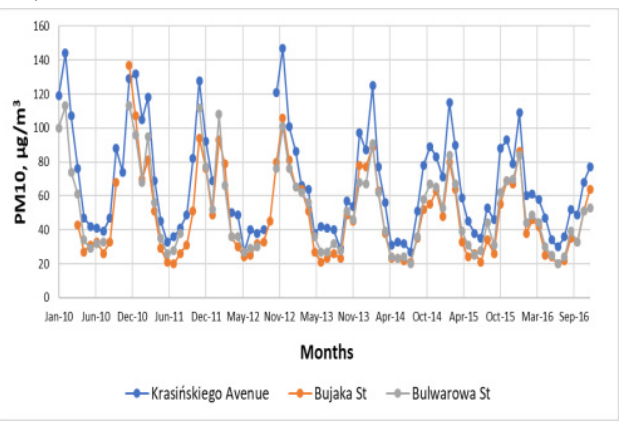

b)

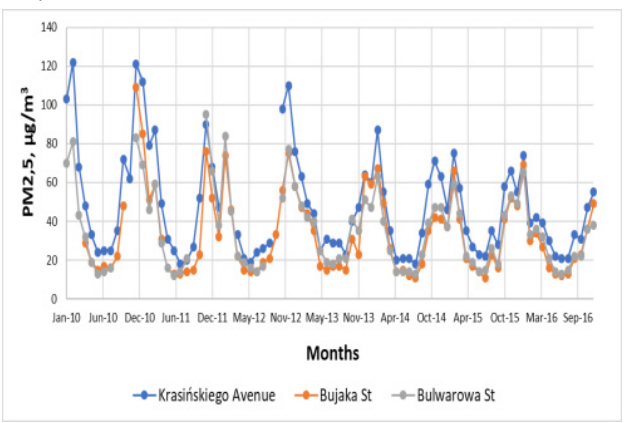

Fig. 4. a) PM10 concentrations in the air in Krakow, b) PM2.5 concentrations in the air in Krakow. Source: own work based on [12]

With regard to air pollution with carbon monoxide, it can be seen that the greatest values are observed in the winter months (with heating). On the other hand, the lowest values can be observed in the warmest (summer) months. As can be seen, the maximum levels of monthly pollution are more than twice higher in comparison with the minimum ones in the particular years. This variability shows that the level of pollution with carbon monoxide is strongly correlated with the season of the year. In the winter months, due to low temperature, there is considerable demand for heating dwellings, which causes high levels of CO concentrations. Pollutant concentrations reach particularly high values, having adverse effect on the health of the inhabitants of Krakow in the winter season during anticyclonic (high pressure) circulation, which is characterised by low temperature, lack or small amount of precipitation, weak wind and thermal inversion. On the other hand, CO concentrations do not exceed the permissible values outside the heating period.

From the analyses, it can be concluded that the levels of air pollution from sulphur dioxide and from suspended particulate matter PM10 and PM2.5 have a similar variability during the year. Also for these pollutants the highest levels are recorded in the winter months, especially when the prevailing type of weather is the anticyclonic one. Also for these pollution indicators the main source of emissions are coal stoves and furnaces. With regard to $\mathrm{NO}_{\mathrm{x}}$, there is no clear correlation between the pollutant levels and the season of the year. This kind of air pollutants in Krakow depends to a large extent on the level of emissions into atmosphere of combustion products from car engines. Generally, however, greater values of this pollutant is observed in the winter season. 


\subsection{Analysis of the correlation between the air quality parameters}

Table 2 presents coefficients of the most correlated pairs of meteorological parameters and air pollutants in Krakow over a period of 84 months (2010-2016). The analysis can serve the purpose of comparison of correlation relations between the factors that determine the air quality in the Urban Municipality of Krakow.

Table 2. Correlation matrix of the air quality parameters.

\begin{tabular}{|l|r|r|r|r|r|r|r|r|}
\hline Parameter & Temperature & Wind & Precipitation & SO $_{2}$ & CO & NO & PM10 & PM2.5 \\
\hline Temperature & 1 & $-0.382^{* *}$ & $0.431^{* *}$ & $-0.839^{* *}$ & $-0.809^{* *}$ & $-0.676^{* *}$ & $-0.864^{* *}$ & $-0.870^{* *}$ \\
\hline Wind & $-0.382^{* *}$ & 1 & 0.005 & $0.275^{*}$ & 0.215 & 0.097 & $0.304^{* *}$ & $0.294^{* *}$ \\
\hline Precipitation & $0.431^{* *}$ & 0.005 & 1 & $-0.393^{* *}$ & $-0.406^{* *}$ & $-0.430^{* *}$ & $-0.482^{* *}$ & $-0.457^{* *}$ \\
\hline $\mathrm{SO}_{2}$ & $-0.839^{* *}$ & $0.275^{*}$ & $-0.393^{* *}$ & 1 & $0.721^{* *}$ & $0.551^{* *}$ & $0.800^{* *}$ & $0.805^{* *}$ \\
\hline $\mathrm{CO}$ & $-0.809^{* *}$ & 0.215 & $-0.406^{* *}$ & $0.721^{* *}$ & 1 & $0.874^{* *}$ & $0.920^{* *}$ & $0.927^{* *}$ \\
\hline $\mathrm{NO}_{\mathrm{x}}$ & $-0.676^{* *}$ & 0.097 & $-0.430^{* *}$ & $0.551^{* *}$ & $0.874^{* *}$ & 1 & $0.826^{* *}$ & $0.824^{* *}$ \\
\hline PM10 & $-0.864^{* *}$ & $0.304^{* *}$ & $-0.482^{* *}$ & $0.800^{* *}$ & $0.920^{* *}$ & $0.826^{* *}$ & 1 & $0.988^{* *}$ \\
\hline PM2.5 & $-0.870^{* *}$ & $0.294^{* *}$ & $-0.457^{* *}$ & $0.805^{* *}$ & $0.927^{* *}$ & $0.824^{* *}$ & $0.988^{* *}$ & 1 \\
\hline
\end{tabular}

** Correlation is significant at the 0.01 level (2-tailed).

* Correlation is significant at the 0.05 level (2-tailed).

Source: own work based on [10,12-13]

In the period analysed, the strongest correlations occurred between gaseous and particulate air pollutants where the correlation coefficients were in the range between 0.800 and 0.927. Strong correlations were also observed between temperature and air pollutants, the coefficients varied from -0.676 to -0.870 . A weaker correlation occurred between the average monthly value of wind velocity and air pollutants (from 0.097 to 0.304 depending on the type of pollutant) as well as between the average monthly total precipitation and air pollutants (from -0.393 to -0.482 ).

The analysis of correlations between the major factors impacting the air quality may provide a basis for the building of a model of predicting the level of pollutants depending on, inter alia, the wind velocity, the temperature, the amount of precipitation and the occurrence of inversion [15-17]. As part of the construction of the prediction model of air pollutants concentrations for Łódź, among others, analysis of the correlation between pollutant concentrations and components of the weather vector was carried out [18].

\subsection{Identification of the factors and remedies}

The analysis of the results obtained shows that two factors have key influence on the variability of air pollution in Krakow. The first of them is low-stack emission from coal stoves, furnaces (domestic heating installations) and boilers. The other factor is the type of meteorological circulation, which is periodically variable. That the lower the temperature the more intensively are the stoves and furnaces used by the inhabitants to heat their dwellings, which contributes to the increased low-stack emission of pollutants. At the same time, other characteristics of high-pressure weather (lack of or weak wind, lack of or low precipitation, thermal inversion) mean that pollutants cannot be dispersed (lack of wind), washed away (lack of precipitation) and transported over greater distances (thermal inversion). As a result, there occurs an accumulation of pollutants to high levels, significantly exceeding the recommended threshold values. High concentrations of 
pollutants (exceeding the limits) frequently persist for several days because high-pressure circulation is a stable pattern.

As follows from the above analysis, atmospheric air pollution in the winter period is the greatest environmental problem of Krakow. The main source of pollutants is low-stack emission from furnaces fuelled with coal and to a smaller extent with wood and waste. It is indicated that the main recipient of thermal and electrical energy is the construction industry, which translates into the growing $\mathrm{CO}_{2}$ emission from this sector [19]. The high level of power consumption in the construction industry results from the poor technical condition and the age structure of the buildings; in many cases, they have not yet been modernised thermally, the energy efficiency of the installations is low and the overwhelmingly greatest proportion of energy comes from conventional sources.

In view of the current situation actions should be taken aimed at first of all improving the air quality in Krakow, and a feasible solution might be taking advantage of the SMART CITY concept. It seems that planning a sustainable and intelligent development of the city in the times of social and economic transformations is a topical challenge.

A smart city is a creative and sustainable one, where life quality is improving, the environment is becoming more and more friendly and the perspectives of the economic development are stronger [20]. An attribute of such cities is intelligence that is interpreted as the sum total of various betterments concerning the functioning of the urban infrastructure and the city's resources as well as public services [21]. In accordance with the Urban Development Strategy 2030, the City of Krakow aspires to be a modern metropolis offering a high quality of living, friendly conditions for innovative economy, a city strong due to its human and social capital, a city managed in a modern way using the ICT technology and at the same time taking into account the inhabitants' aspirations and their participation in public life [22]. Due to the very bad air quality, it seems justifiable to implement the smart city concept first of all in the area of Krakow's environmental issues that are directly related with enduring good air quality in the city. For this purpose it is necessary to effectively implement the anti-smog resolution as well as the programme of reducing low-stack emission, which together provide the citizens with full access to information on the options of their participation in purifying the air in the city.

\section{Conclusions}

1. The research shows that air pollution in Krakow with $\mathrm{CO}$ carbon oxide, $\mathrm{SO}_{2}$ sulphur dioxide and from suspended particulate matter PM10 and PM2.5 is the highest in the winter months (in the heating season). On the other hand, the lowest values can be observed in the warmest (summer) months. For these pollution indicators the main source of emissions are coal stoves and furnaces. With regard to $\mathrm{NO}_{\mathrm{x}}$, there is no clear correlation between the pollutant levels and the season of the year. Generally, however, greater values of this pollutant is observed in the winter season. This kind of air pollutants in Krakow depends to a large extent on the level of emissions into atmosphere of combustion products from car engines.

2. The positive correlations between the average monthly value of wind velocity and air pollutants as well as between the average monthly total precipitation and air pollutants and also negative correlation between temperature and air pollutants confirm the thesis concerning the decisive impact of anticyclonic circulation on the high concentrations of pollutants and exceedances of the limit values in the heating period (formation of winter smog) in Krakow.

3. In order to reduce the level of air pollution in Krakow, especially in the heating period, it is above all necessary to intensify efforts aimed at eliminating coal and wood fuelled stoves, furnaces and boilers. This can be accomplished through subsidising the 
replacement of existing stoves and furnace with heating appliances characterised by low emissions of pollutants and further development of the central heating network. Additionally, it is necessary, among other things, to expand the scope of thermal modernisations and other modernisation work on energy installations in buildings; also, the network of cycling paths should be developed.

4. A feasible solution contributing to the improvement of air quality in Krakow might be taking advantage of the smart city concept. For this purpose, it is necessary to effectively implement the "anti-smog resolution" as well as the programme of reducing low-stack emission, which together provide the citizens with full access to information on the options of their participation in purifying the air in the city.

\section{References}

1. A. D. Wilson, Procedia Technol., 1, 453-463 (2012)

2. B. Chen, H. Kan, Environ. Health Prev Med., 13, 94-101 (2008)

3. M. Krzyżanowski, J. Toxicol. Environ. Health A., 71, 47-50 (2008)

4. D. Fuksa, E. Ciszyńska, Komputerowo zintegrowane zarzadzanie, 1, 446-455 (2010)

5. GUS, Zuzycie energii w gospodarstwach domowych w 2015 r., Warszawa (2017)

6. A. Malec, G. Borowski, Inżynieria Ekologiczna, 50, 161-170 (2016)

7. K. Juda-Rezler, Oddziaływanie zanieczyszczeń powietrza na środowisko (Oficyna Wydaw. Politechniki Warszawskiej, Warszawa, 2006)

8. W. Hanke, Zanieczyszczone powietrze powoduje śmiertelne choroby, Tworzymy atmosferę

9. Państwowy Monitoring Środowiska - Inspekcja Ochrony Środowiska, Warszawa (2014)

10. GUS, Ochrona Środowiska 2011-2017, Warszawa (2017)

11. Raporty o stanie Miasta za lata 2015-2016, Urząd Miasta Krakowa, Wydział Rozwoju Miasta, Kraków (2017)

12. Wojewódzki Inspektorat Ochrony Środowiska w Krakowie, System monitoringu jakości powietrza

13. Serwis METEO, Zespół fizyki środowiska, Wydział Fizyki i Informatyki Stosowanej, AGH, Kraków (2017)

14. Rozporządzenie Ministra Środowiska z dnia 24 sierpnia 2012 r. (Dz. U z 2012 r., poz. 1031)

15. B. Tashayo, A. Alimohammadi, A. (2016), Environ. Sci. Pollut. R., 23, 19, 19417 -19431 (2016)

16. A. Venkatram (Ed.), Lectures on air pollution modeling (Springer, 2015)

17. P. Zannetti, P. (Ed.), Air pollution modeling: theories, computational methods and available software (Springer Science \& Business Media, 2013)

18. J. Skrzypski, Analiza i modelowanie pól imisji zanieczyszczeń powietrza $w$ dużych miastach (Komisja Ochrony Środowiska PAN Oddział w Łodzi, Łódź, 2002)

19. M. J. Molina, L. T. Molina, J. Air Waste Manag. Assoc., 54, 644-680 (2004)

20. J. H. Lee, M. Gong Hancock, M.-Ch. Hu, Technol. Forec. \& S. Ch., 89, 80-99 (2014)

21. S. Allwinkle, P. Cruickshank, J. of Urban Techn., 18, 1-16 (2011)

22. Strategia Rozwoju Krakowa 2030, Kraków (2016) 